International Journal of Agriculture, Environment and Bioresearch

Vol. 4, No. 03; 2019

ISSN: $2456-8643$

\title{
INTER PROVINCIAL COMPARISON OF AGRICULTURAL PRODUCTIVITY IN MOZAMBIQUE
}

\author{
Custodio Efraim Matavel $^{1}$; Angelo Cuiana ${ }^{1}$; Luisa Paulo Mondlane ${ }^{1}$ and Sofia Moniz Martinho $^{1}$ \\ 1Faculty of Agrarian Sciences, Universidade Lúrio, Niassa Province, Unango Campus, Sanga District, Mozambique \\ http://doi.org/10.35410/IJAEB.2019.242249
}

\begin{abstract}
The Government of Mozambique adopted a constitution in 1990;therefore, it has made great efforts to achieve agricultural growth. The present paper analyzes the agricultural productivity of Mozambique in the period 2007-2017, using data obtained from the national agricultural census of 2009-2010 and the National Statistical Institute. Cobb-Douglas production function was used to calculate the production elasticity's of the output determinants. Productivity estimates showed that northern area is the most productive in Mozambique, with Niassa province having the highest productivity. Human capital, fertilizer use, and livestock production are the determinants of productivity that have shown significant and positive elasticity's either within the province as well as between provinces
\end{abstract}

Keywords: agricultural productivity; elasticity of production; Mozambique

\section{INTRODUCTION}

Since 1990, agriculture in Mozambique has been constitutionally defined as the basis of national development [1]. Since then, the government has made great efforts to achieve agricultural growth. However, despite employing around $70 \%$ of the population [2], the contribution of agricultural sector to Gross Domestic Product (GDP) has been decreasing in recent years [3]. Currently, its contribution to GDP is around 22.5\%[4]. Among the causes for poor performance are the low labor productivity in agriculture [2], low education levels of farmers, inefficient use of production factors of (capital, land, labor and inputs)[5], lack of access to credit and consultancy services [6].

Zavale, Mabaya \& Christy (2005) and Uaiene \& Arndt (2009)used data at the national level to study the determinants of inefficiencies in Mozambican agriculture. However, in their analyzes they assume that access to technology is homogeneous among provinces located in the same agro-ecological zone, therefore, the estimates may be biased [8]. National statistics indicate important differences, which have a large impact on agricultural production, among the eleven Mozambican provinces. There are differences in the use of animal traction (mostly concentrated in the South), use of fertilizers and pesticides and irrigation infrastructures. [9].Hence, it becomes necessary to study productivity using an approach that considers these differences. 
In order to capture regional differences, Yaguchi(1994)suggests the use of panel data to estimate agricultural productivity at the national or global level, which consists of grouping crosssectional and time-series data. Griliches (1963)was one of the pioneers to use this type of grouping to measure the growth of agricultural productivity. One of the advantages of using pooled data is to be able to construct a multivariate model without suffering a severe multicollinearity that usually arises when using time series data [10]. Hayami \& Ruttan (1985)applied the grouping technique to estimate what they call "international meta-production function", which is the integration of the production function of each of the 43 countries they studied. Marinho e Carvalho (2004)used the meta-production function to make inter-regional comparisons of agricultural productivity in Brazil. The objective of this study is to analyze the differences in productivity among Mozambican provinces in the period from 2007 to 2017 through a meta-production function.

\section{METHODOLOGY}

\subsection{Source of data and description of variables}

The main sources of data used in this study were the 2009-2010 agricultural census [14] and the Statistical Yearbooks published by the National Institute of Statistics of Mozambique ${ }^{1}$. The data refer to the 11 Mozambican provinces in the period from 2007 to 2017, forming a panel of 176 observations. Total agricultural output and all conventional inputs such as labor, land, livestock, fertilizers and mechanization were converted on a farm scale by dividing the original data by the total number of farms in each province. The level of schooling and the number of graduates in the field of agriculture per 1000 agricultural workers are used as proxy for human capital.

\subsection{Analytical framework}

The approach used for data analysis was the Cobb-Douglas production function. Its mathematical expression is as follows:

$$
\begin{aligned}
& \ln y_{\text {it }}=\ln \alpha+\sum_{m=1}^{7} \beta_{m} \ln X_{\text {imit }}+e_{\text {it }} \quad \text { (1) } \\
& t=2007,2008, \ldots \ldots, 2017 ; i=1, \cdots, 11
\end{aligned}
$$

Wherelndenotes natural logarithm, $y_{i t}$ is the agricultural production, wis the intercept assumed to be constant over timetand through the cross-sectional units, $x_{\text {imt }}$ represents the inputs, $\beta_{m}$ it's a slope of the input mwhich is also assumed to be constant over time $t$ and through cross-sectional units.

In the production function specifications, dummy variables were incorporated to capture differences in productivity within and between provinces over time [15].Thus, the algebraic form of the productivity function is:

$$
y_{\text {it }}=f(X) e^{\pi_{i}+Y_{i x}}
$$

\footnotetext{
${ }^{1}$ http://www.ine.gov.mz/estatisticas/publicacoes/anuario
} 
Where $Y_{i \mathrm{i}} \mathrm{i}$ the total agricultural output in the province $i$ at year $t, \mathrm{X}$ is the inputs vector, $\alpha_{\mathrm{i}}$ is the province-specific coefficient, $\gamma_{i}$ is the time-specific coefficientand $f(X)$ is the Cobb-Douglas production function. Thus, the coefficients $\alpha_{i}$ and $\gamma_{i}$ represent the estimates of the productivity level in each province and the changes in productivity over time, respectively.

Four regression models are estimated. The first model (model 1) is estimated with the assumption that there is no province or time effects, that is $\alpha_{i}=\gamma_{i}=0$ for alli.In the second model, $\gamma_{i}=0$, in the third model $\alpha_{i}=0$ and the fourth model is unrestricted, in other words, it is assumed the be an effect of the province, as well as the time.

\section{RESULTS AND DISCUSSION}

\subsection{National agricultural productivity}

The estimates of the agricultural productivity parameters are presented in table 1. It can be seen in table 1 that the inclusion of the dummy variable for the province significantly affects the coefficients of labor, land and mechanization. The coefficient of labor reduces from 0.63 in model 1 to almost zero in models 2 and 4 (values of the t-statistic equal to 1.83 and 1.41 , respectively).The estimates presented in models 2 and 4 allow the identification of the variation that occurs within the province and the estimates presented in models 1 and 3 are based on the interprovincial variations. Thus, the coefficients of models 1 and 3 reflect the long-term productivity adjustment.

\section{Table1: Results of the Production function}

\begin{tabular}{|c|c|c|c|c|}
\hline \multirow[b]{2}{*}{ Variables } & \multicolumn{4}{|l|}{ Model } \\
\hline & 1 & 2 & 3 & 4 \\
\hline Labor & $\begin{array}{l}0.632 \\
(7.87) \\
\end{array}$ & $\begin{array}{l}0.0567 \\
(1.83)\end{array}$ & $\begin{array}{l}0.536 \\
(6.33) \\
\end{array}$ & $\begin{array}{l}0.031 \\
(1.41)\end{array}$ \\
\hline Land & $\begin{array}{l}0.028 \\
(1.03)\end{array}$ & $\begin{array}{l}0.356 \\
(3.167)\end{array}$ & $\begin{array}{l}0.0403 \\
(1.254) \\
\end{array}$ & $\begin{array}{l}0.59 \\
(4.059) \\
\end{array}$ \\
\hline Fertilizers & $\begin{array}{l}0.197 \\
(2.498)\end{array}$ & $\begin{array}{l}0.09 \\
(4.01)\end{array}$ & $\begin{array}{l}0.124 \\
(3.78)\end{array}$ & $\begin{array}{l}0.082 \\
(4.70)\end{array}$ \\
\hline livestock & $\begin{array}{l}0.182 \\
(2.73)\end{array}$ & $\begin{array}{l}0.185 \\
(2.117\end{array}$ & $\begin{array}{l}0.351 \\
(6.8)\end{array}$ & $\begin{array}{l}0.422 \\
(10.85)\end{array}$ \\
\hline Mechanization & $\begin{array}{l}0.099 \\
(3.9) \\
\end{array}$ & $\begin{array}{l}0.058 \\
(3.436 \\
\end{array}$ & $\begin{array}{l}0.047 \\
(1.66)\end{array}$ & $\begin{array}{l}0.018 \\
(1.41) \\
\end{array}$ \\
\hline Schooling Years & $\begin{array}{l}0.042 \\
(1.92)\end{array}$ & $\begin{array}{l}0.168 \\
(0.65 \\
\end{array}$ & $\begin{array}{l}0.153 \\
(0.6) \\
\end{array}$ & $\begin{array}{l}1.3 \\
(0.53) \\
\end{array}$ \\
\hline $\begin{array}{l}\text { Graduates in } \\
\text { Agriculture }\end{array}$ & $\begin{array}{l}0.135 \\
(3.89) \\
\end{array}$ & $\begin{array}{l}0.135 \\
(2.987 \\
\end{array}$ & $\begin{array}{l}0.142 \\
(4.525)\end{array}$ & $\begin{array}{l}0.155 \\
(4.615) \\
\end{array}$ \\
\hline Constant & $\begin{array}{l}1.905 \\
(4.789)\end{array}$ & $\begin{array}{l}2.147 \\
(2.684)\end{array}$ & $\begin{array}{l}2.207 \\
(1.254)\end{array}$ & $\begin{array}{l}2.097 \\
(1.345)\end{array}$ \\
\hline
\end{tabular}




\begin{tabular}{|lllll|}
\hline Specification of: & & & & \\
\hline Province & - & Yes & - & Yes \\
\hline Time & - & - & Yes & Yes \\
\hline$\sum$ Sum $^{*}$ & 1.138 & 0.7457 & 1.0983 & 1.143 \\
\hline $\mathrm{R}^{2}$ & 0.995 & 0.915 & 0.962 & 0.906 \\
\hline Conditional index & 12.9 & 14.1 & 11.4 & 12.7 \\
\hline
\end{tabular}

*Sum of variables coefficients, with exception of literacy and graduates in agriculture In parentheses the are the values of $t$-statistic

Problems of labor productivity, which seems to be stationary within the province (models 2 and 4), may be consistent with the low levels of adoption of new production technologies reported by Leonardo (2017), besides that, this is a costly process and takes a lot of time [15], [17]. This means that with existing farming and land tenure systems, the labor productivity may remain unchanged and, therefore, to increase the agricultural production it will be necessary an increase in agricultural workforce. A reduction in the supply of labor could create a shortage of labor for agriculture and significantly reduce productivity [18]. Similarly, the emigration of rural population may create productivity problems in agriculture if the technology remains unchanged. The land, on the other hand, shows a tendency contrary to the labor force. Land productivity within the province is significantly different from zero in models 2 and 4 . Therefore, the positive changes in agricultural outputs at provincial levels reported by the Ministry of Agriculture [19] are a result of increased land productivity.

The number of graduates in technical education as well as the use of fertilizers and livestock has positive effects on productivity, both at provincial level, as well as between provinces. This reveals the importance of human capital[10]and inputs use intensity in agricultural productivity[5], therefore, policies focused on promoting technical education in agriculture, expansion of cultivated land and use of technical inputs may have better results in increasing productivity within Mozambican provinces.

\section{Interprovincial and regional variations of Productivity}

Table 2 shows the province specific estimates calculated in the complete model (model 4 of table 1). The provinces were sorted according to their corresponding $e^{\alpha_{i}}$ estimates. According to the results, with an identical collection of inputs, Maputo province presents $56 \%$ of the productivity presented by Nampula province (considered in the model as $e^{\mathbb{E}_{i}}=1$ ). Niassa province is $78 \%$ more productive than Nampula, due to the fact that, despite having a very small population density, it is one of the provinces that mostly contributes to national production of staple foods[20].

Estimates reflect rather significant interprovincial differences in the efficiency of agricultural production and resource use, but the annual productivity $\gamma_{\mathrm{i}}$ changes are below 5\% in all provinces. Maputo city, despite being the one with the highest levels of use of agricultural inputs, has the least productivity (38\% of Nampula productivity), this is consistent with the fact that it is 
very urbanized and presents a lower rate of agricultural workers. Therefore, increasing the supply of labor in agriculture can increase efficiency in agriculture.

Table2: province and time-specific coefficients

\begin{tabular}{|llll|}
\hline Province & $100 *^{\mathbb{E}_{i}}$ & $\gamma_{\mathrm{i}}$ & Ranking \\
\hline Niassa & 178 & 2.6 & $1^{\text {st }}$ \\
\hline $\begin{array}{l}\text { Cabo } \\
\text { Delgado }\end{array}$ & 133 & 2.3 & $2^{\text {nd }}$ \\
\hline Gaza & 127 & 2.1 & $3^{\text {rd }}$ \\
\hline Manica & 115 & 2.1 & $4^{\text {th }}$ \\
\hline Sofala & 109 & 1.7 & $5^{\text {th }}$ \\
\hline Nampula & 100 & 1.4 & $6^{\text {th }}$ \\
\hline Tete & 81 & 1.2 & $7^{\text {th }}$ \\
\hline Inhambane & 79 & 0.9 & $8^{\text {th }}$ \\
\hline Zambézia & 69 & 0.8 & $9^{\text {th }}$ \\
\hline $\begin{array}{l}\text { Maputo } \\
\text { Província }\end{array}$ & 56 & 0.9 & $10^{\text {th }}$ \\
\hline Maputo City & 38 & 0.2 & $11^{\text {th }}$ \\
\hline
\end{tabular}

$100 * e^{\Phi_{1}}$ - Percentage in relation to Nampula

$\gamma_{\mathrm{i}}-$ Percent change per year

Based on the results of table 2, it can be observed that the northern region, composed of the provinces of Cabo-delgado, Nampula and Niassa, is the most productive. In this sense, in order to verify how far the Central and Southern regions are from the North regarding the productivity, assuming that differences in agricultural productivity can be expressed by the sum of the percentage differences in input productivity atfarm level (each input associated with its mean elasticity, obtained by the Cobb-Douglas function), the following equation was generated:

$$
\begin{aligned}
& \frac{y_{N}-y_{n}}{y_{N}}=0.3\left(\frac{M_{N}-M_{n}}{M_{N}}\right)+0.25\left(\frac{T_{N}-T_{n}}{T_{N}}\right)+0.12\left(\frac{E_{N}-E_{n}}{F_{N}}\right)+0.29\left(\frac{E P_{N}-E P_{n}}{E P_{N}}\right)+0.06\left(\frac{M e_{N}-M e_{n}}{M e_{N}}\right)+0.42\left(\frac{A_{N}-A_{n}}{A_{N}}\right)+ \\
& 0.14\left(\frac{E_{N}-E_{n}}{E_{N}}\right)
\end{aligned}
$$

Where $\mathrm{y}$ is the total agricultural output, $\mathrm{M}$ represents labor, $\mathrm{T}$ is land, $\mathrm{EP}$ is livestock, $\mathrm{F}$ fertilizers, Me mechanization, A the level of schooling and Ed is the number of graduates in the agriculture for each 1000 agricultural workers. $N$ e $n$ denote the North and Central or South regions, respectively.The results of the calculations are presented in Table 3. 
Table3: differences in productivity per farm unit (North-South and North-Center)

\begin{tabular}{|lllll|}
\hline $\begin{array}{l}\text { Difference in } \\
\text { productivity } \\
\text { per farm unit }\end{array}$ & 0.32 & $(100 \%)^{*}$ & 0.16 & $(100 \%)^{*}$ \\
\cline { 2 - 6 } $\begin{array}{l}\text { Percentage of } \\
\text { explained } \\
\text { difference } \\
\text { total }\end{array}$ & 0.313 & $(98 \%)$ & 0.124 & $(78 \%)$ \\
\hline & & & & \\
\hline $\begin{array}{l}\text { Accumulation } \\
\text { of Resources }\end{array}$ & 0.0615 & $(19 \%)$ & 0.033 & $(21 \%)$ \\
\hline Land & 0.0396 & $(12 \%)$ & 0.0188 & $12 \%$ \\
\hline Livestock & 0.0101 & $(3 \%)$ & 0.0062 & $4 \%$ \\
\hline Labor & 0.0118 & $(4 \%)$ & 0.008 & $8 \%$ \\
\hline & & & & \\
\hline $\begin{array}{l}\text { Technical } \\
\text { inputs }\end{array}$ & 0.0525 & $(16 \%)$ & 0.0298 & $(19 \%)$ \\
\hline Fertilizers & 0.0418 & $(13 \%)$ & 0.0186 & $(12 \%)$ \\
\hline Mechanization & 0.0107 & $(3 \%)$ & 0.0112 & $(7 \%)$ \\
\hline & & & & \\
\hline $\begin{array}{l}\text { Human } \\
\text { Capital }\end{array}$ & 0.199 & $(62 \%)$ & 0.0612 & $(38 \%)$ \\
\hline $\begin{array}{l}\text { Schooling } \\
\text { Years }\end{array}$ & 0.0605 & $(19 \%)$ & 0.0092 & $(6 \%)$ \\
\hline $\begin{array}{l}\text { Technical } \\
\text { Education }\end{array}$ & 0.1385 & $(43 \%)$ & 0.052 & $(33 \%)$ \\
\hline
\end{tabular}

*In parentheses are percentages of productivity, standardized for $100 \%$

The productivity gap between the North and South regions is $32 \%$ and between the Central and North regions is $16 \%$. The variables in the model explain $98 \%$ and $78 \%$ of the variation observed between the North and Central regions and North and South regions, respectively.Human capital explains most of the differences for both cases (North-South and North-Center). This implies that human capital is more effectively used in the Northern region than in the South and Center, followed by land. Access to education in a key factor to increase agricultural outputs in Mozambique [6]. Moreover, the expansion of land can also play a significant role in enhancing the growth of agricultural productivity[7]. 


\section{CONCLUSIONS}

The analyzes we made, allowed to obtain the production elasticities of the different determinants of agricultural productivity. It was also possible to verify the productivity differences between and within the provinces. Based on the results it is concluded that over time, few increases in agricultural productivity took place in Mozambique from 2007 to 2017, given the fact that the time-specific estimates are below 5\% in all provinces. This may have to do with the low levels of new technologies adoption. However, there are significant differences in productivity among the 11 provinces. Maputo City is the least productive and Niassa province is the most productive. Among the determinants of productivity, human capital, fertilizers use and livestock production showed significant and positive elasticities both within and between provinces, which implies that these factors are very important for agricultural productivity in Mozambique. In this regard, policies that promote investments in human capital, livestock production and improvement of soil fertility are recommended in this research.

\section{REFERENCES}

[1] GdM, “CONSTITUIÇÃO DA REPÚBLICA DE MOÇAMBIQUE DE 1990.” Governo de Moçambique, Maputo, 2004.

[2] R. Ali, C. N. Castel-Branco, and C. Muianga, Emprego e transformação económica e social em Moçambique. Maputo: IESE, 2017.

[3] BM, "Actualidade Económica de Moçambique: Tirando proveito da transformação demográfica," Maputo, 2017.

[4] INE, “Contas Nacionais de Moçambique: IV Trimestre 2018,” Maputo, 2019.

[5] C. E. Guanziroli and T. Guanziroli, "Modernização da Agricultura em Moçambique: determinantes da renda agrícola," Rev. Econ. e Sociol. Rural, vol. 53, no. suppl 1, pp. 115-128, Mar. 2015.

[6] R. N. Uaiene and C. Arndt, "Farm Household Efficiency in Mozambique," in International Association of Agricultural Economists Conference, 2009, pp. 1-20.

[7] H. Zavale, E. Mabaya, and R. Christy, "Smallholders' cost efficiency in Mozambique: Implications for improved maize seed adoption," 2004-04, 2005.

[8] R. R. Nelson, “A 'Diffusion' Model of International Productivity Differences in Manufacturing Industry,” Am. Econ. Rev., vol. 58, no. 5, pp. 1219-1248, 1968.

[9] T. A. Sitoe, "Agricultura familiar em Moçambique estratégias de desenvolvimento sustentável,” p. 31, 2005.

[10] Y. Yaguchi, "A panel data approach to the intercountry metaproduction function," Iowa State University, 1994.

[11] Z. Griliches, "The Sources of Measured Productivity Growth: United States Agriculture," 
J. Polit. Econ., vol. 71, no. 4, pp. 331-346, 1963.

[12] Y. Hayami and V. W. Ruttan, Agricultural development: an international perspective. Johns Hopkins University Press, 1985.

[13] E. Marinho and R. M. Carvalho, "COMPARAÇÕES INTER-REGIONAIS DA PRODUTIVIDADE DA AGRICULTURA BRASILEIRA-1970-1995," Pesqui. Planej. Econ., vol. 34, no. 1, pp. 57-92, 2004.

[14] INE, “CENSO AGRO-PECUÁRIO - Mocambique: 2009-2010," Instituto Nacional de Estatistica- CENSO AGRO-PECUÁRIO. Instituto Nacional de Estatistica, Maputo, 2011.

[15] R. E. Evenson and Y. Kislev, Agricultural research and productivity. Yale University Press, 1975.

[16] W. J. Leonardo, Exploring opportunities for rural livelihoods and food security in Central Mozambique. 2017.

[17] R. E. Evenson, "Economic impacts of agricultural research and extension," in Handbook of Agricultural Economics, vol. 1, London, UK: Elsevier, 2001, pp. 573-628.

[18] T. Schultz, "Transforming Traditional Agriculture," Econ. J., vol. 74, no. 296, pp. 996999, 1964.

[19] MINAG, “Anuário de Estatísticas Agrárias 2012-2014." Ministério da Agricultura, Maputo, pp. 1-59, 2014.

[20] MINAG, "Plano Nacional De Investimento Do Sector Agrário." Ministerio da Agricultura, Maputo, pp. 1-85, 2013. 